\title{
Effect of influent flow rate distribution on the performance of step-feed biological nitrogen removal process
}

\author{
Guibing Zhu ${ }^{\mathrm{a}, \mathrm{b}}$, Yongzhen Peng ${ }^{\mathrm{a}, \mathrm{c}, *}$, Shuying Wang ${ }^{\mathrm{c}}$, Shuyun $\mathrm{Wu}^{\mathrm{a}}$, Bin Ma ${ }^{\mathrm{a}}$ \\ ${ }^{a}$ School of Municipal and Environmental Engineering, Harbin Institute of Technology, Harbin 150090, China \\ ${ }^{\mathrm{b}}$ Research Center for Eco-Environmental Science, Chinese Academy of Sciences, Beijing 100085, China \\ ${ }^{\mathrm{c}}$ Key Laboratory of Beijing Water Quality Science and Water Environment Recovery Engineering, \\ Beijing University of Technology, Beijing 100022, China
}

Received 10 February 2006; received in revised form 28 October 2006; accepted 7 December 2006

\begin{abstract}
The step-feed anoxic/oxic biological nitrogen removal process has been proposed as an attractive alternative for the conventional biological nitrogen removal process for the purpose of enhanced nitrogen removal. For step-feed process, the biological nitrogen removal efficiency is a function of influent flow distribution. In this study, the effects of influent flow rate distribution on the performance of nitrogen removal process were investigated. The effects of influent flow rate distribution on COD, ammonia, total nitrogen removal efficiency, nitrification rate and sludge volume index value were also studied. According to the performance characteristic of the step-feed process, the concept of influent flow rate distribution ratio was firstly introduced. The maximum influent flow distribution ratios $\left(\lambda_{\max }\right)$ under the condition of different influent $\mathrm{C} / \mathrm{N}$ ratios were determined, respectively, by trial and error method. The experimental results showed that high total nitrogen removal efficiency, higher than $95 \%$, could be achieved under certain influent flow rate distribution ratio without internal nitrate cycle or addition of external carbon source. It was obvious that nitrification rate of each stage under different influent flow distributions decreased along with the decreasing of sludge loading and volume loading in each stage, and the degree of reduction rise gradually with the increasing of influent flow distribution ratio. The sludge volume index value would also increase along with the increase of influent flow distribution ratio.
\end{abstract}

(C) 2006 Elsevier B.V. All rights reserved.

Keywords: Activated sludge; Biological nitrogen removal; C/N ratio; Flow rate distribution; Removal efficiency; Step-feed process

\section{Introduction}

To protect lakes and other natural water from eutrophication, stringent nutrient level is set for the effluents from the wastewater treatment plants. Most of the plants recently employ biological process. Various biological nutrient removal processes such as pre-denitrification process $(\mathrm{A} / \mathrm{O})$, anaerobic/anoxic/aerobic process (A2/O), University of Cape Town (UCT), modified Bardenpho processes and Virginia Initiative Plant (VIP) were developed and widely applied [1-6]. These approaches will require additional energy for liquid circulation and addition of external carbon substrate for denitrification in anoxic zones. Further due to the growth of autotrophic nitrifying organisms in the aerobic tank, external addition of alkaline source is necessary to

\footnotetext{
* Corresponding authors at: School of Municipal and Environmental Engineering, Harbin Institute of Technology, Harbin 150090, China.

E-mail address: guibingzhu@163.com (G.B. Zhu).
}

neutralize $\mathrm{pH}$. As a result, the operational cost of these processes will increase significantly. To overcome these, the step-feed biological nitrogen removal (SFBNR) process has increasingly been proposed as an attractive alternative. Usually, this proposed process consist two or more stages of denitrification-nitrification reactors in series. For SFBNR process, the energy for internal recycle is not necessary. In addition the solids retention time (SRT) can increase because of suspended solids gradient along the reactors [7]. As a consequence of these features the process has been found to offer relevant advantages for both new and existing plants $[8,9]$

However, the optimum design and operation of the step-feed process is a difficult task because of step feeding of influent flow and complexity of reactor configuration. Volume ratios of anoxic and aerobic zone and wastewater fraction to be diverted from the inlet of the system are important parameters to be considered in the design of the step-feed process. Wastewater characteristics, especially influent $\mathrm{C} / \mathrm{N}$ ratio, significantly affect the design and operation. 
During the last decade, many researchers have put much attention to this process and drawn many valuable conclusions. In the aspects of theoretical analysis [10], theoretically analyzed on nitrogen removal of the step-feed anoxic-oxic activated sludge process and its application for the optimal operation. Compared with the conventional denitrification-nitrification process, the step-feed process with four stages might reduce about $25 \%$ the total reactor volume [11,7]. Practically, when summarizing the conceptual approach and evaluating the operation of Riva plant (in Istanbul) [12], found that the number of stages influenced significantly the operation and nitrogen removal efficiency in step-feeding system. Compared with the conventional denitrification-nitrification process, the step-feed process with three stages might reduce about $20 \%$ the hydraulic retention time. The Newtown creek wastewater treatment plant, the largest plant in New York City, was reconstructed utilizing step-feed process for enhanced biological nitrogen removal in 1996. The operating results from January 1997 to June 1998 showed the BOD (biochemical oxygen demand), SS (suspended solids) and total nitrogen removal efficiency was $82-86.1 \%, 84.5-89.5 \%$ and $76-85 \%$, respectively $[13,9]$. The Lethbridge wastewater treatment plant in Canada was retrofitted as five stages step-feed process for biological nutrient removal (BNR). The operating results showed the average mixed liquid suspended solids (MLSS) and treatment ability was higher than conventional BNR process. The average effluent ammonia and nitrate concentration was lower than 0.5 and $5 \mathrm{mg} / \mathrm{L}$, respectively, in the whole year of 1999 [8].

The total nitrogen removal efficiency can be enhanced for conventional biological nitrogen removal process given better influent wastewater feeding mode. The previous studies results also showed that biological nitrogen removal efficiency is a function of influent flow distribution [14]. But there is no further reports about the effect of influent flow rate distribution on the performance of step-feed biological nitrogen removal process [15,11]. In this study, this effect will be evaluated. Moreover, than this, the effects of influent flow rate distribution on ammonia and total nitrogen removal efficiency, nitrification rate and sludge volume index value will also be examined.

\section{Material and methods}

\subsection{Reactor system}

A four stages step-feed biological nitrogen removal process made of plexiglass with a working volume of $80 \mathrm{~L}$ was used in this study (Fig. 1). The two channels cuboid reactor has a dimension of $80 \mathrm{~cm} \times 22 \mathrm{~cm} \times 50 \mathrm{~cm}$. Each stage consisted of an anoxic and an aerobic zone, and the ratio of anoxic reactor volume and aerobic was maintained at 1:3.5 for four same stages in this study. For maintaining plug-flow purpose and concentration gradient, the aerobic zones in each stage are separated by clapboards as three joint compartments. A mechanical mixer was used in anoxic zone to provide liquid mix well. A number of outlets for samples were placed at a distance of $20 \mathrm{~cm}$ from reactor bottom in each anoxic and aerobic compartment. An air compressor was used for aeration. An air flow meter was used for controlling the airflow rate in reactor. The type of final clarifiers is a vertical clarifier with working volume of $30 \mathrm{~L}$.

\subsection{Wastewater composition}

The reactor feed consisted of synthetic wastewater with characteristics similar to those of domestic wastewater [16]. It was prepared by using tap water, dechlorinated by the use of sodium thiosulfate, and the addition of chemicals as indicated in Table 1. A few of glucose and amylum that are not very easily biodegradable organic materials were also added to supplement COD. In addition some other organic materials such as glucose and maltose also exist in the brewery wastewater. Nitrogen and phosphorus were adjusted by adding $\mathrm{NH}_{4} \mathrm{Cl}$ and $\mathrm{KH}_{2} \mathrm{PO}_{4}$ to the feed water. Sodium bicarbonate was also added to adjust alkalinity. The wastewater was continuously fed to the reactor and the flow rates were controlled by four peristaltic pumps (Model ESBN4, Iwaka Cop. Japan), respectively.

\subsection{Experimental operating procedure}

The start-up of the SFBNR process was initiated by seeding the synthetic wastewater with the sludge came from the secondary clarifier of Harbin Wenchang wastewater treatment plant (A/O process, $100,000 \mathrm{~m}^{3} /$ day), while the reactor was operated for 12 days in a batch mode to provide the initial colonization and accumulation of microorganisms. The reactor was then operated in a continuous flow mode by gradually increasing flow to promote bacterial growth. Steady state was reached after 28 days of operation. Once the steady-state was realized, various experiments were conducted under a total of eight different $\mathrm{C} / \mathrm{N}$ ratios in which total nitrogen concentrations were maintained constant at $42 \mathrm{mg} / \mathrm{L}$ ( $40 \mathrm{mg} / \mathrm{L}$ of kjeldahl nitrogen concentrations) so as to compare the effluent total nitrogen concentration and total nitrogen removal efficiency.

During the experimental period, the SRT was controlled at 18 days using hydraulic control approach. The sludge returns ratio was set at 50 percent of influent flow rate controlled by a peristaltic pump (Model Z1515-18, Lange Bump Cop, China). The temperature of the reactor was kept at $22 \pm 1{ }^{\circ} \mathrm{C}$ by temperature controller.

Table 1

Composition of synthetic wastewater

\begin{tabular}{lc}
\hline Compound & Concentration $(\mathrm{mg} / \mathrm{L})$ \\
\hline Brewery wastewater & $9500-10500$ \\
Glucose & $500-650$ \\
Starch & $200-250$ \\
$\mathrm{NH}_{4} \mathrm{Cl}$ & 114.6 \\
$\mathrm{NaHCO}_{3}$ & 900.0 \\
$\mathrm{MgSO}_{4} \cdot 7 \mathrm{H}_{2} \mathrm{O}$ & 150.0 \\
$\mathrm{NaCl}_{\mathrm{CaCl}}$ & 110.0 \\
$\mathrm{ZnSO}_{4}$ & 85.5 \\
\hline
\end{tabular}




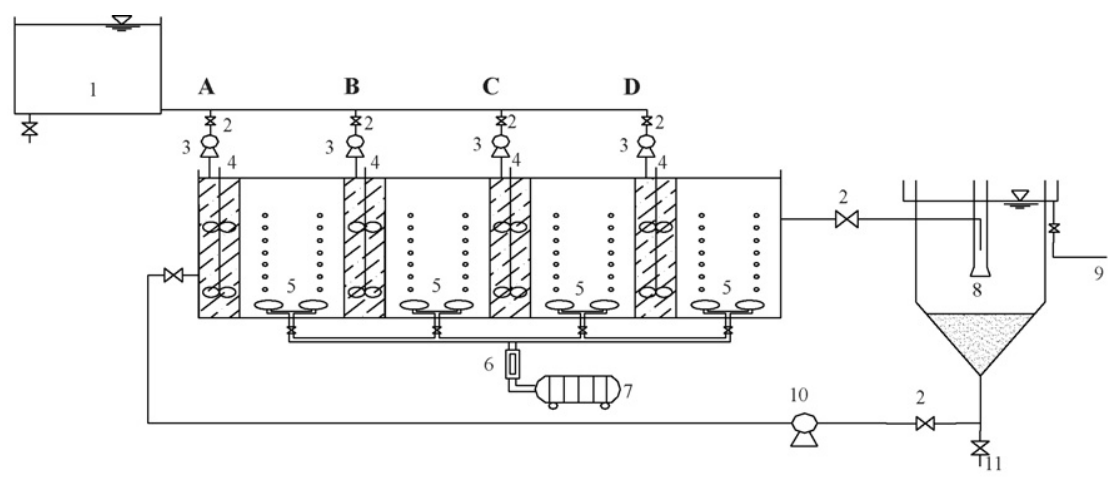

1. influent tank 2. check valve 3. feed pump 4. mechanical mixer 5. diffuser 6. air flow meter 7. air compressor 8 . secondary clarifier 9 . effluent 10 . return sludge pump 11 . waste sludge

Fig. 1. Schematic diagram of step-feed biological nitrogen removal process.

\subsection{Samples and analytical procedures}

The parameters measured including $\mathrm{pH}$, temperature, $\mathrm{DO}$, COD, $\mathrm{NH}_{4}{ }^{+}-\mathrm{N}, \mathrm{TKN}, \mathrm{NO}_{2}{ }^{-}-\mathrm{N}, \mathrm{NO}_{3}{ }^{-}-\mathrm{N}$, MLSS, SVI, TN and alkalinity. Samples were prepared by filtering with $0.45 \mathrm{um}$ Whatman filter papers. The measurements of $\mathrm{DO}, \mathrm{pH}$ and temperature of wastewater were conducted daily using WTW pH/Oxi 340i (made in Germany). The type of probe of DO and pH was WTW CellOx 325 and pH-Electrode SenTix 4, respectively. All analyses were performed according to the Standard Methods [17].

\section{Results and discussions}

\subsection{Introduction of influent flow distribution ratio $(\lambda)$}

For this proposed process, theoretically, the biological nitrogen removal efficiency $(\eta)$ for SFBNR process can be calculated by the following equation [7]:

$\eta=\left(1-\frac{\alpha}{1+R}\right) \times 100 \%$

where $\alpha$ is the ratio of flow rate distribution into the last stage to total influent flow rate and $R$ is the sludge return ratio.

The concentration of total nitrogen in the effluent is determined by the kjeldahl nitrogen in the aerobic zone of the last stage, only if in each stage, complete nitrification and denitrification in aerobic and anoxic zone are realized, respectively. In the last stage, where there is no nitrate accumulation and the inflow is at the minimum ratio, total nitrogen concentration in the effluent can maintain at the lowest level.

To promise the nitrate formed in each stage to be denitrified completely, the carbon source is provided by the influent of the next stage. Under certain influent $\mathrm{C} / \mathrm{N}$ ratio, there must be a maximum influent flow distribution ratio $\left(\lambda_{\max }\right)$ between the last two stages, which is critical for lowest effluent total nitrogen concentration. Universally, this ratio value $\left(\lambda_{1,2} \ldots\right)$ exists between the first and second stage, the second and third stage, and so on. In theory, this ratio value $\left(\lambda_{i}, i=1,2, \ldots, \max \right)$ would be equal if the reaction is completely for every stage. However, for step-feed process, different sludge concentrations occur because
Table 2

The maximum influent flow rate distribution ratio under different influent $\mathrm{C} / \mathrm{N}$ ratios

\begin{tabular}{ll}
\hline Influent $\mathrm{C} / \mathrm{N}$ ratio & Maximum influent flow distribution ratio $\left(\lambda_{\max }\right)$ \\
\hline 6.75 & 1.75 \\
8 & 2 \\
9.25 & 2.25 \\
10.5 & 2.5 \\
11.75 & 2.75 \\
13 & 3 \\
15 & 3.5 \\
17 & 4
\end{tabular}

the returned sludge will be unevenly distributed by the step-feed wastewater in each stage. So, assimilation varies even between two contiguous stages. In practice, the $\lambda_{i}$ between any two stages will be larger than that between backward contiguous two stages. For example, $\lambda_{1}>\lambda_{2}>\cdots>\lambda_{\max }$. For a process with four or five stages, there would be three or four $\lambda_{i}$. It would be tedious to get the each $\lambda_{i}$ through checking all the values. But this ratio should be around the value of $\lambda_{\max }$, especially when the $\lambda_{\max }$ is large. From the standpoint of process control, optimal operation and management, a uniform distribution ratio $\left(\lambda_{\max }\right)$ can be introduced in the process of influent flow rate splitting.

The influent flow distribution ratio $\left(\lambda_{\max }\right)$ is determined by the wastewater influent $\mathrm{C} / \mathrm{N}$ ratio, and the value is unique under certain influent $\mathrm{C} / \mathrm{N}$ ratio. The value of $\lambda_{\max }$ should be ascertained through the experimental methodology by trial and error

Table 3

Percent of $\mathrm{NH}_{4}{ }^{+}-\mathrm{N}$ removal

\begin{tabular}{llllll}
\hline$\lambda$ & \multicolumn{4}{l}{ Percent removal $(\%)$} & \\
\cline { 2 - 6 } & Stage 1 & Stage 2 & Stage 3 & Stage 4 & Overall \\
\hline 1.75 & 72.35 & 73.60 & 92.75 & 100.0 & 100.0 \\
2 & 69.37 & 71.37 & 92.25 & 100.0 & 100.0 \\
2.25 & 66.67 & 69.23 & 91.67 & 100.0 & 100.0 \\
2.5 & 65.79 & 69.55 & 86.96 & 100.0 & 100.0 \\
2.75 & 65.79 & 69.55 & 86.96 & 100.0 & 100.0 \\
3 & 62.39 & 65.57 & 76.92 & 100.0 & 100.0 \\
3.5 & 60.14 & 73.02 & 82.61 & 100.0 & 100.0 \\
4 & 59.80 & 78.13 & 95.41 & 100.0 & 100.0 \\
\hline
\end{tabular}



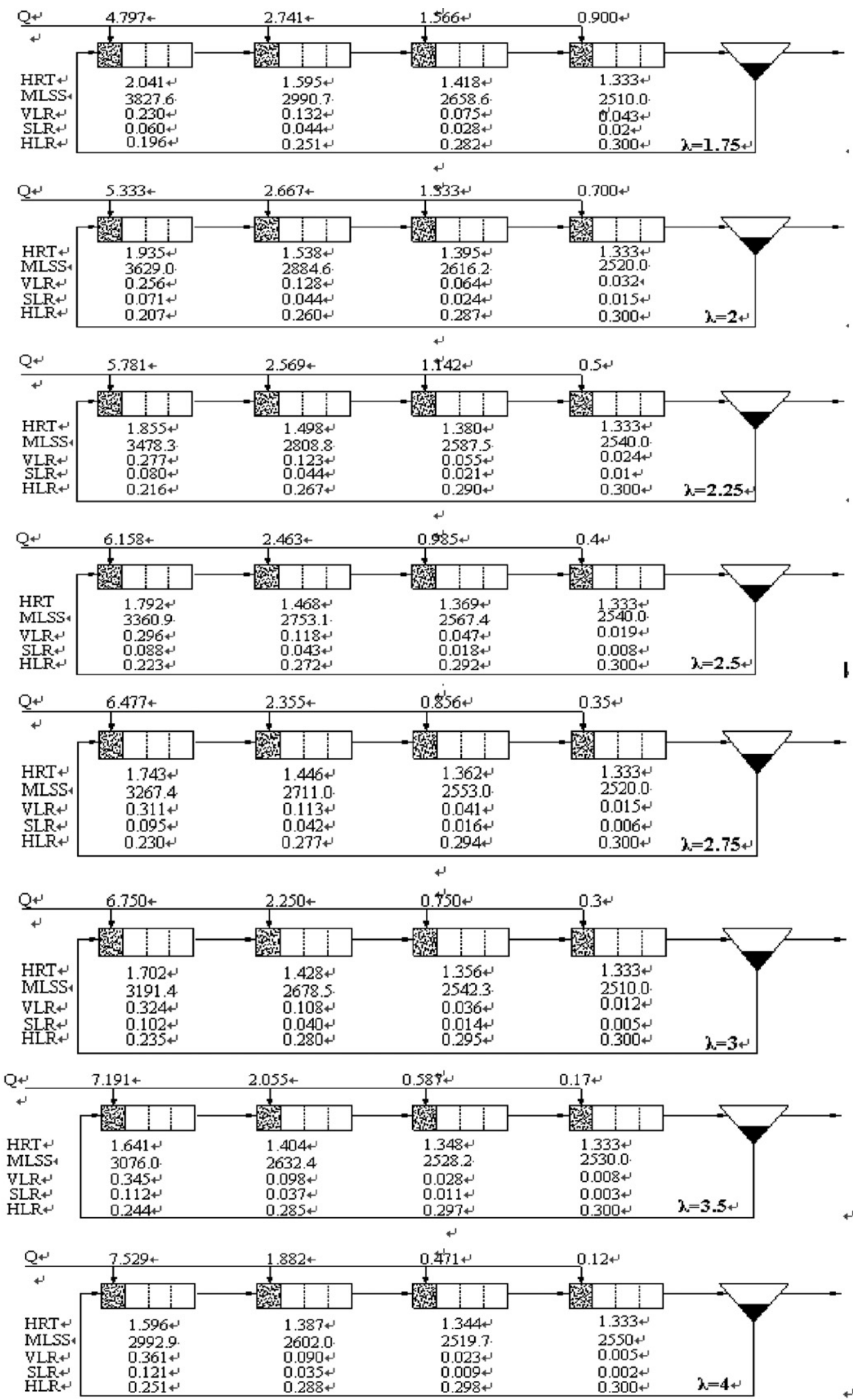

$\mathrm{Q}$ (flow rate) in $\left(\mathrm{Lh}^{-1}\right)$, HRT (hydraulic retention time) in (hrs), MLSS (mixed liquid suspended solids) in $\left(\mathrm{mgL}^{-1}\right)$, VLR (volumetric loading rate) in $\left(\operatorname{kgCOD}\left(\mathrm{m}^{3} \cdot \mathrm{d}\right)^{-1}\right)$, SLR (sludge rate loading) in ( $\left.\mathrm{kgCOD}(\mathrm{kgMLSS} . \mathrm{d})^{-1}\right)$, and HLR (hydraulic rate loading) in $\left(\mathrm{m}^{3}\left(\mathrm{~m}^{2} . \mathrm{d}\right)^{-1}\right)$

Fig. 2. Summary of steady-state operating conditions for various influent flow rate distribution ratios. 

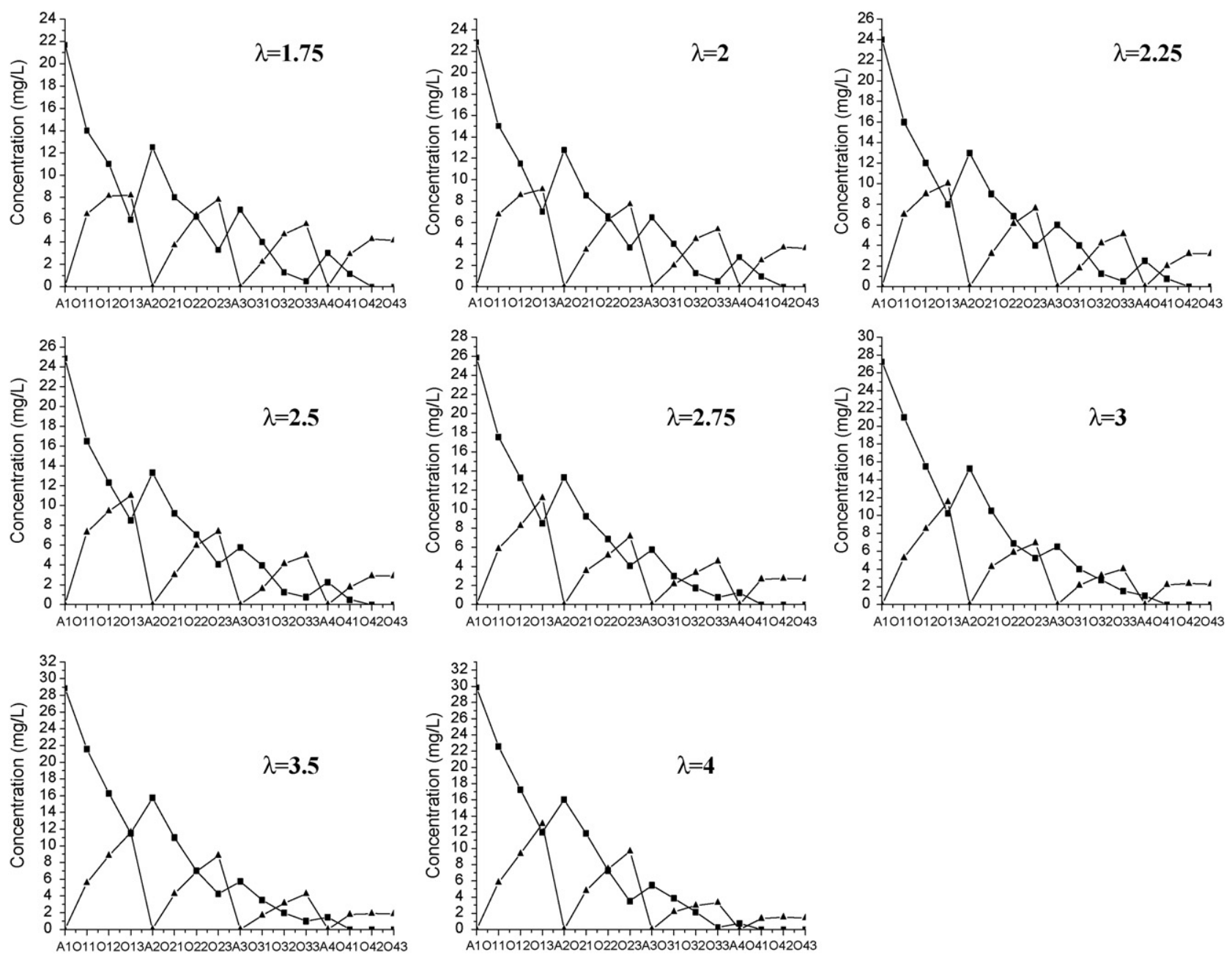

Fig. 3. Stage effluent parametric concentration for various influent flow distribution ratios. In the $X$-axis alphabetic number A means anoxic zone, $\mathrm{O}$ means oxic zone, and the Arabic numerals mean the stage and the compartment, respectively: (ם) $\mathrm{NH}_{4}{ }^{+}-\mathrm{N}$; (ム) $\mathrm{NO}_{X}-\mathrm{N}$.

method, which is the tedious and time-wasting working. Once the value of $\lambda_{\max }$ is determined, the influent flow rate in each stage can be calculated by the following equation:

$Q_{\text {Total }}=\lambda_{\max }^{n-1} X+\lambda_{\max }^{n-2} X+\cdots+\lambda_{\max } X+X$

In which $n$ is the number of stage and $X$ is the influent flow rate distributing in the last stage.

\subsection{The effect of influent flow distribution on the} performance of step-feed biological nitrogen removal process

The maximum influent flow rate distribution ratios $\left(\lambda_{\max }\right)$ were drawn under the different influent $\mathrm{C} / \mathrm{N}$ ratios according to the principle mentioned above by the trial and error method. The experimental results for maximum influent flow rate distribution ratios were shown in Table 2. The steady-state operating con-

Table 4

Stage effluent COD concentrations

\begin{tabular}{|c|c|c|c|c|c|c|c|c|}
\hline \multirow[t]{2}{*}{$\lambda$} & \multicolumn{2}{|l|}{ Stage $1(\mathrm{mg} / \mathrm{L})$} & \multicolumn{2}{|l|}{ Stage $2(\mathrm{mg} / \mathrm{L})$} & \multicolumn{2}{|l|}{ Stage $3(\mathrm{mg} / \mathrm{L})$} & \multicolumn{2}{|l|}{ Stage $4(\mathrm{mg} / \mathrm{L})$} \\
\hline & Anoxic effluent & Aerobic effluent & Anoxic effluent & Aerobic effluent & Anoxic effluent & Aerobic effluent & Anoxic effluent & Aerobic effluent \\
\hline 1.75 & 100 & 36 & 57 & 26 & 55 & 24 & 38 & 16 \\
\hline 2 & 123 & 36 & 58 & 28 & 56 & 26 & 36 & 14 \\
\hline 2.25 & 144 & 48 & 62 & 36 & 54 & 30 & 40 & 16 \\
\hline 2.5 & 168 & 56 & 62 & 36 & 54 & 24 & 38 & 16 \\
\hline 2.75 & 204 & 72 & 84 & 38 & 56 & 26 & 36 & 16 \\
\hline 3 & 252 & 80 & 104 & 42 & 56 & 28 & 34 & 14 \\
\hline 3.5 & 288 & 96 & 112 & 48 & 46 & 24 & 32 & 12 \\
\hline 4 & 324 & 106 & 124 & 56 & 46 & 24 & 30 & 11 \\
\hline
\end{tabular}



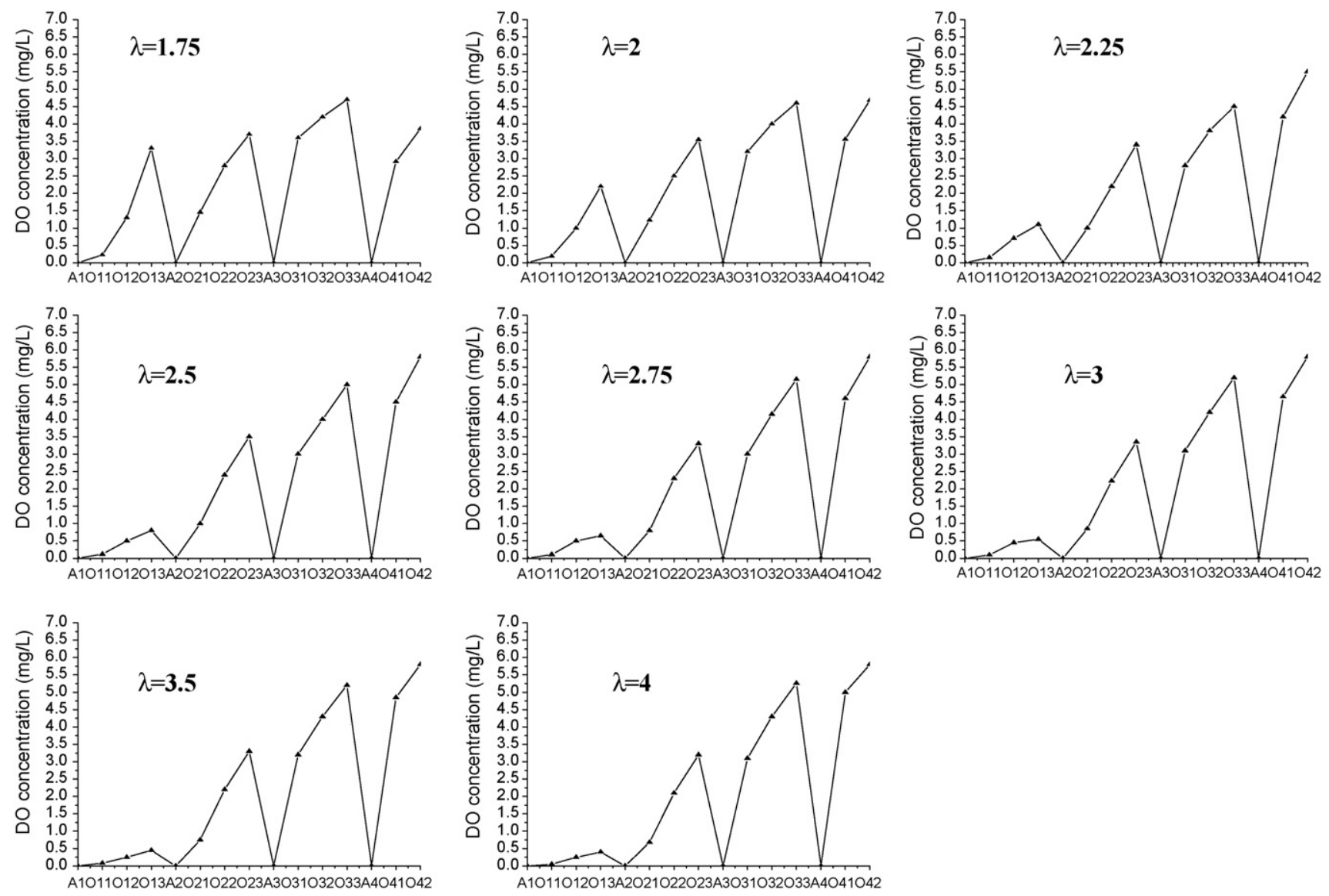

Fig. 4. Variations of DO concentration in each reactor under for various influent flow distribution ratios.

ditions for various maximum influents flow distribution ratios were shown in Fig. 2. With certain influent $\mathrm{C} / \mathrm{N}$ ratio the maximum influent flow distribution ratio in the process of influent flow rate splitting was definite. Similarly, the resulting effluent $\mathrm{NH}_{4}{ }^{+}-\mathrm{N}$ and $\mathrm{NO}_{X}-\mathrm{N}$ concentrations were shown in Fig. 3.

In this study, numbered cases to adjust the ratio of anoxic and aerobic reactor volumes of every stage were also made. As prementioned in step-feed process the concentration of total nitrogen in the effluent can be determined by the kjeldahl nitrogen in the aerobic zone of the last stage if complete nitrification and denitrification in aerobic and anoxic zone are accomplished in each stage. To achieve complete nitrification in each stage, volume adjusting will bring some effects, but it will not improve significantly tot-N removal efficiency. Under certain influent flow distribution ratio, changing the volume of anoxic zone will not enhance the extent of denitrification. For example, when influent $\mathrm{C} / \mathrm{N}$ ratio is 13 , the maximum influent flow distribution ratio can only reach 3 . So whether the denitrification performs completely or not is not only decided by the volume of the anoxic zone, but also mainly by the influent $\mathrm{COD}$ rate. At this $\mathrm{C} / \mathrm{N}$ ratio, the influent flow distribution ratio will not be changed through enlarging the volume of anoxic zone. For real domestic or municipal wastewater, increasing HRT of each anoxic phase by adjusting volume ratio will give chance of slowly biodegradable COD converted into readily biodegradable COD $[18,19]$. But in this paper this effect is

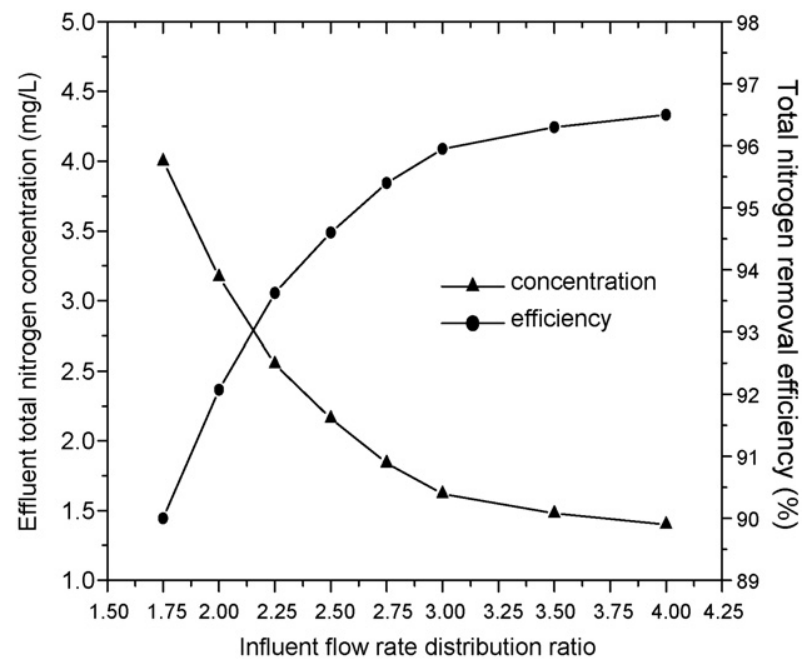

Fig. 5. Effluent total nitrogen concentration and total nitrogen removal efficiency under certain influent flow distribution ratios. In figure, the abscissa denotes the maximum influent flow distribution ratios $\left(\lambda_{\max }\right)$ under the condition of different influent $\mathrm{C} / \mathrm{N}$ ratios. The main ordinate denotes the total nitrogen concentration when operating under the condition of the maximum influent flow distribution ratios. The sub-ordinate axis denotes the total nitrogen removal efficiency accordingly. 
insignificant because the synthetic wastewater is prepared with brewery wastewater and a few of glucose and amylum that are not very easily biodegradable organic materials were also added.

In addition, if influent carbon is enough and complete nitrification in each stage, the total nitrogen removal efficiency under the influent flow distribution ratio of 1:3:3:3 is lower than the value obtained from $1: 5: 3: 1$, no matte how to adjust the ratio of anoxic and aerobic zone volumes.

\subsection{The effect of influent flow distribution on the biological nitrogen removal}

The percent of $\mathrm{NH}_{4}{ }^{+}-\mathrm{N}$ removal and effluent COD concentrations in each stage were shown in Tables 3 and 4, respectively. One hundred percent of $\mathrm{NH}_{4}{ }^{+}-\mathrm{N}$ removal efficiency in the fourth stage under various influent flow distribution ratios was achieved although the hydraulic loading rate was high. From Tables 3 and 4 and Fig. 2 it was also noted that the $\mathrm{NH}_{4}{ }^{+}-\mathrm{N}$ removal efficiency decreased along with the increasing of volumetric loading rate and sludge loading rate, accordingly to the results of [20-22]. However, a marked difference was noted that from $58.66 \%(\mathrm{C} / \mathrm{N}$ ratio $=17)$ to $65.79 \%(\mathrm{C} / \mathrm{N}$ ratio $=9.25)$ of $\mathrm{NH}_{4}{ }^{+}-\mathrm{N}$ removal efficiency could be achieved in the first stage despite the volumetric rate loading and sludge rate loading was high, especially under high influent flow distribution ratios condition, which were opposite to the results of [23-25]. However, these were attributed to the presence of simultaneous nitrification and denitrification.

In step-feed biological nitrogen process, the sludge returns to the first stage of the reactor. Fig. 2 illustrates the step distribution of MLSS concentration. The MLSS concentration will reach $3900 \mathrm{mg} / \mathrm{L}$ in the first stage. Higher MLSS concentration is benefit to simultaneous nitrification and denitrification $[26,27]$. Moreover, DO concentration is a very critical factor to affect SND. In this experiment the DO concentrations under different influent flow distribution ratios have also been studied, and shown in Fig. 4. When the process is operated with a
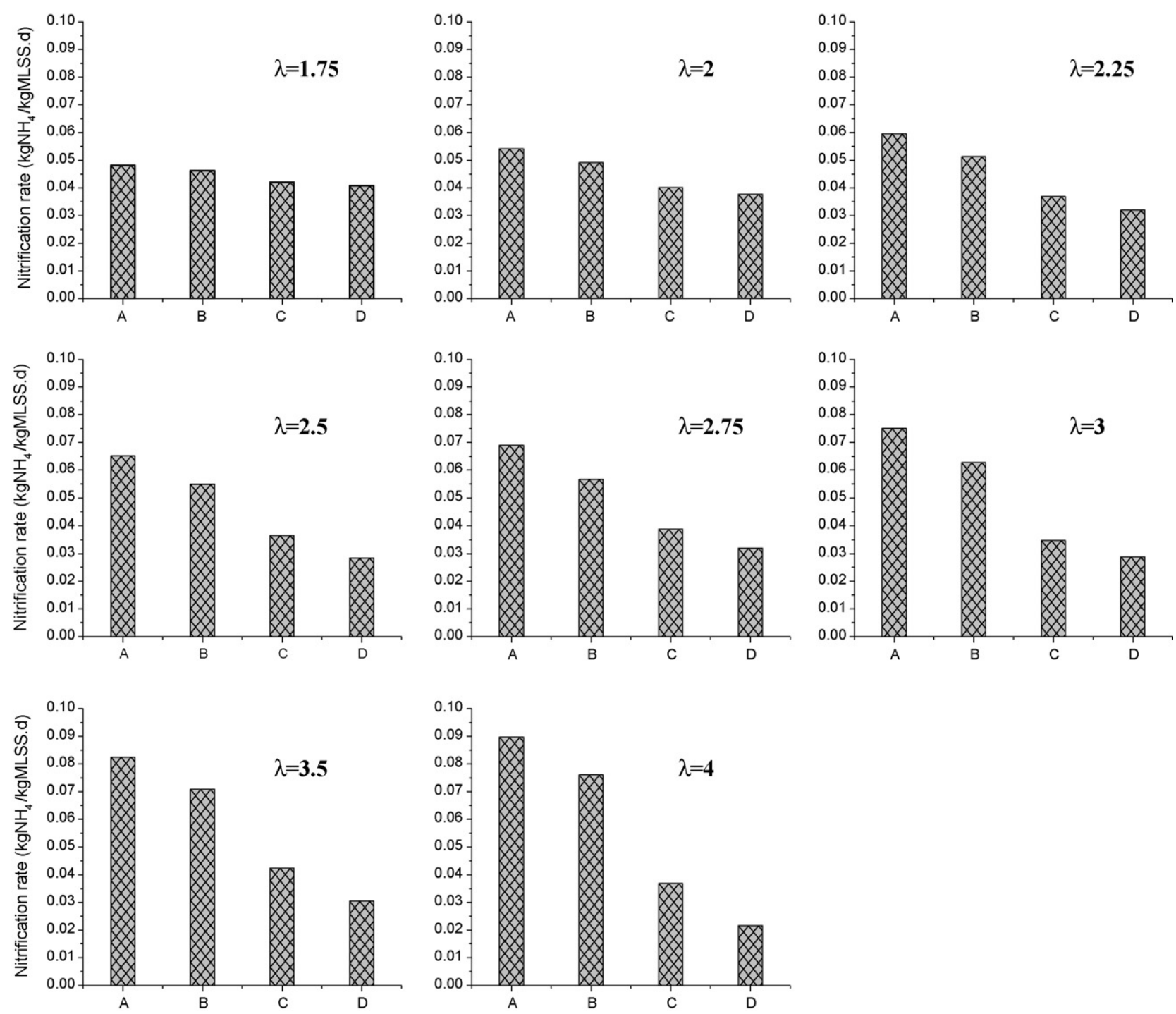

Fig. 6. The nitrification rate under different influent flow rate distribution ratios. The ordinate denotes the nitrification rates of different stages. In the abscissa the alphabetic number A-D means the number of stage. 


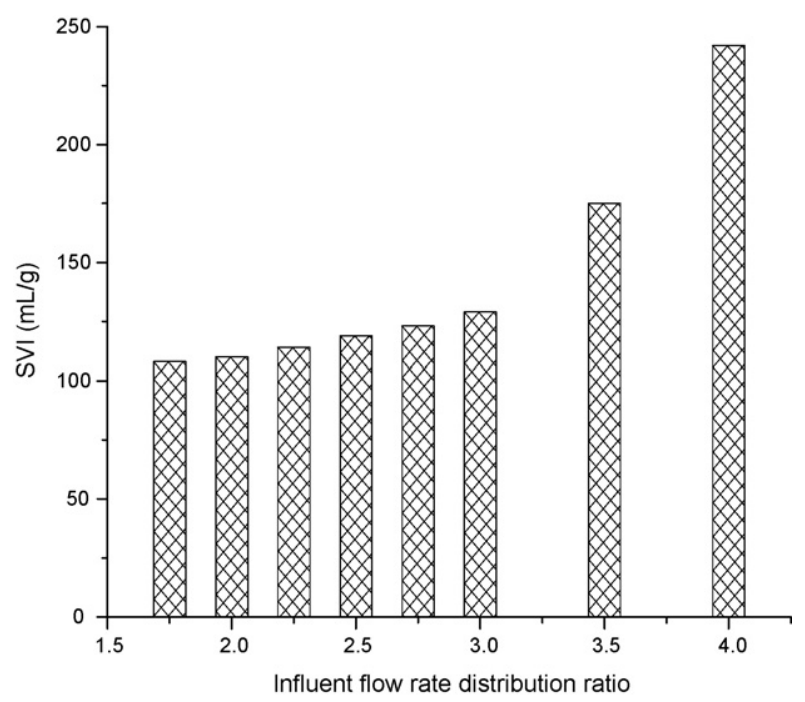

Fig. 7. Variation of sludge volume index under different influent flow rate distribution ratios.

certain influent flow rate ratio, DO is severely deficient in some stage. Those factors attribute to the occurrence of SND [28-30]. During recent years microbiologists have shown that nitrifying as well as denitrifying are of greater physiological variety than expected. Certain species of bacteria such as Nitrosomonas europea and Nitrosomonas eutropha are able to denitrify aerobically [31-33]. However, many heterotrophic organisms have been found to be able to nitrify organic and inorganic nitrogen compounds $[34,35]$. Details about simultaneous nitrification and denitrification would be discussed in another article [36].

Effluent total nitrogen concentration and removal efficiency under certain influent flow distribution ratios were shown in Fig. 5. From Fig. 5 it should be emphasized that high total nitrogen removal efficiency, higher than $95 \%$, could be obtained in step-feed biological nitrogen removal process under certain influent flow distribution ratio. When influent flow rate distribution ratio increased from 1.75 to 4 , the total nitrogen removal efficiency could increase from $90.2 \%$ to $96.5 \%$. But for conventional pre-denitrification process, $1850 \%$ internal recycle ratio is needed as well as $50 \%$ sludge recycle ratio. In theory, the tot-N removal efficiency formula of pre-denitrification process is described as Eq. (3) [4]:

$\eta=\frac{R+r}{1+R+r}$

in which $R$ is the internal recycle ratio, $r$ the sludge return ratio and $\eta$ is the removal efficiency

Assuming $r$ equals to $50 \%$ and $\eta$ equals to $95 \%$, we can get the value of $R$ is $1850 \%$. Because of microorganism assimilation and SND, it would be below this value in practical. But it is
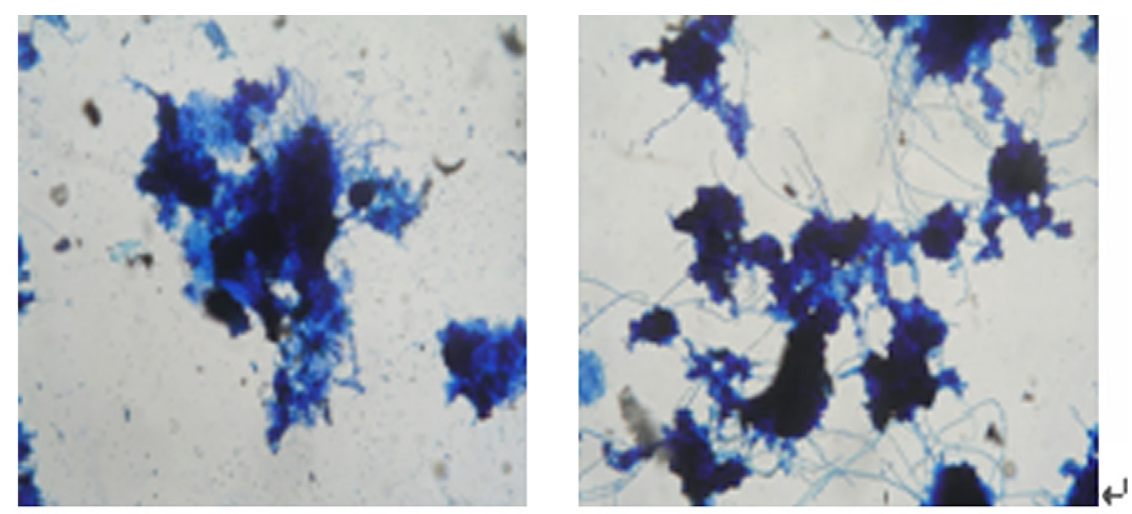

$\leftarrow$

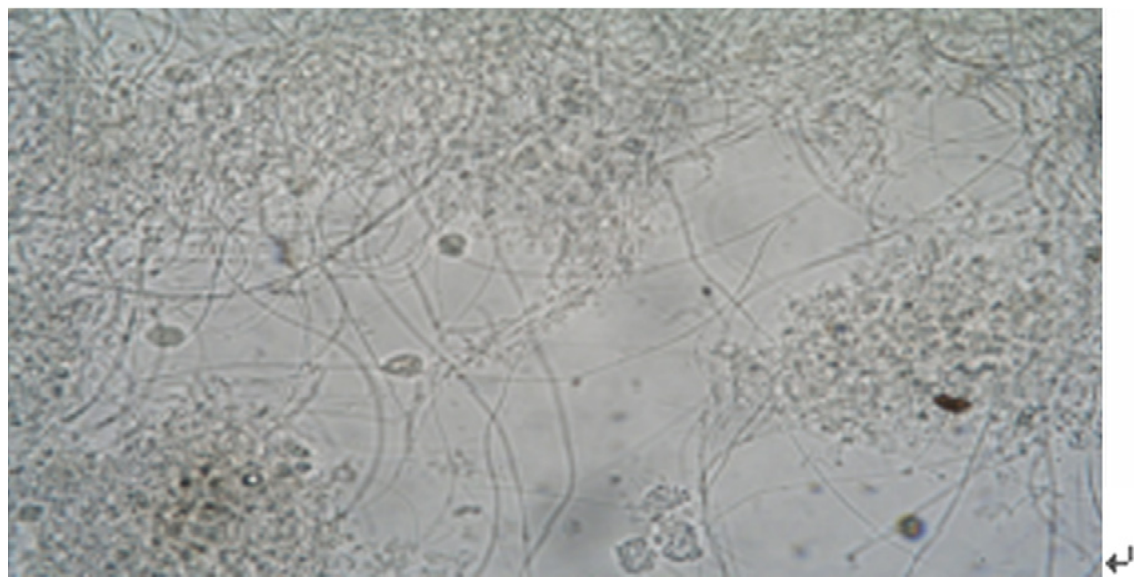

Fig. 8. Typical microbial photograph under the conditions of different flow rate distribution ratios. Left: $\lambda=1.75$; right: $\lambda=2.75$; bottom: $\lambda=4$. When $\lambda=1.75$ or 2.75 , the sludge was sampled to take picture after dyeing with Loeffler. When $\lambda=4$, the sludge was taken to take picture without dyeing. The magnification is $40 \times 10=400$ times. 
obvious that step-feed process has distinct advantage over the pre-denitrification process in saving operation costs.

The nitrification rates of each stage under different influent flow distribution ratios were calculated and shown in Fig. 6. From the figure the nitrification rates were all higher than the reported value of conventional biological nitrification rate [37], indicating the high efficiency of the step-feed process. Combined Figs. 2 and 6, it was obvious that nitrification rate decreased along with the decreasing of sludge loading and volume loading rate in each stage, especially when the process was operated at higher influent flow distribution ratio. The degree of reduction rose gradually with the increasing of influent flow distribution ratio. This would be significant for the process operation practically. At the cases of higher influent ammonia concentration, relative large part of influent flow should be attributed to the former stage so as to maintain the final effluent ammonia concentration at a low level.

\subsection{Effect of influent flow distribution on sludge volume index}

The sludge volumetric index (SVI) was also examined during the experimental period. After the process operating under a maximum influent flow distribution ratio $\left(\lambda_{\max }\right)$ and reaching in a steady condition, the sludge was sampled to measure the SVI value and make images of microorganism. The SVI value increased along with the increasing of influent flow rate distribution ratio, shown in Fig. 7. There were lots of filamentous bacterial in activated sludge under microscope (Fig. 8). The main reason for filamentous bacteria sludge bulking could be attributed to the high organic loading rate in the first stage and inefficient DO concentration. When influent flow rate distribution ratio was 3.5 , for example, the concentration of DO in the first compartment of aerobic zone of the first stage was only $0.07 \mathrm{mg} / \mathrm{L}$. But the SVI value could be returned to normal value after adjusting the influent flow distribution and feeding averagely. From the standpoint of loading equilibration and preventing filamentous bacteria sludge bulking, the relative average influent flow distribution should be maintained for certain TN removal efficiency.

\section{Conclusions}

The laboratory pilot scale studies were conducted to evaluate the effect of influent flow rate distribution on the performance of step-feed biological nitrogen removal process. The results of the study demonstrated that improvements in the total nitrogen removal efficiency of the step-feed biological nitrogen removal process could be obtained by adjusting influent flow rate distribution under certain $\mathrm{C} / \mathrm{N}$ ratio. In particular the following conclusions are arrived at:

(1) The influent flow rate distribution ratio was firstly introduced in the step-feed process based on the performance characteristic. Under the condition of different influent $\mathrm{C} / \mathrm{N}$ ratios of $9.25,10.5,11.75,13,15$ and 17 , the maximum influent flow distribution ratio $\left(\lambda_{\max }\right)$ was $1.75,2,2.25,2.5$,
$2.75,3,3.5$ and 4 , respectively, according to the principle by the trial and error methods, and the total nitrogen removal efficiency was $90 \%, 92.075 \%, 93.625 \%, 94.6 \%, 95.4 \%$, $95.95 \%, 96.3 \%$ and $96.5 \%$, respectively, when there was no accumulation of nitrate in anoxic zone of the last stage and the minimum influent flow rate in the last stage.

(2) The total nitrogen removal efficiency of the step-feed biological nitrogen removal process was a function of influent flow rate distribution ratio, whereas the maximum influent flow distribution ratio $\left(\lambda_{\max }\right)$ was determined by the influent $\mathrm{C} / \mathrm{N}$ ratio.

(3) Relative high nitrification rate, higher than $0.085 \mathrm{~kg}$ $\mathrm{NH}_{4} /(\mathrm{kg}$ MLSS day) was achieved in the step-feed process. It was obvious that the nitrification rate of each stage decreased along with the decreasing of sludge loading and volume loading in each stage, especially when the process was operated at higher influent flow distribution ratio. The degree of reduction rose gradually with the increasing of influent flow distribution ratio. At the cases of higher influent ammonia concentration, relative large part of influent flow should be attributed to the former stage so as to maintain the final effluent ammonia concentration at low level.

(4) The sludge volume index value would also increase along with the increasing of influent flow distribution ratio. From the standpoint of loading equilibration and preventing filamentous bacteria sludge bulking, the relative lower influent flow distribution ratio should be adopted for certain TN removal efficiency.

\section{Acknowledgements}

This research was funded jointly by key international cooperative programs of NSFC (no. 50521140075), National High Technology Research and Development Program (863 Program) of China (no. 2004AA601020) and Attached projects of " 863 " project of Beijing Municipal Science and Technology (Z0005186040421).

\section{References}

[1] M.C. Wentzel, G.A. Ekama, G.V.R. Marais, Process and modelling of nitrification denitrification biological excess phosphorus removal systems-a review, Wat. Sci. Technol. 25 (6) (1992) 59-82.

[2] K. Østgaard, M. Christensson, E. Lie, K. Jönsson, T. Welander, Anoxic biological phosphorus removal in a full-scale UCT process, Wat. Res. 31 (11) (1997) 2719-2726.

[3] S.C. Williams, J. Beresford, The effect of anaerobic zone mixing on the performance of a three-stage Bardenpho plant, Wat. Sci. Technol. 38 (1) (1998) 55-62.

[4] George Tchobanoglous, F.L. Burton, H.D. Stensel. Wastewater Engineering: Treatment Disposal and Reuse, 4th ed. Metcalf and Eddy Inc., McGraw-Hill, New York, 2003.

[5] Guibing Zhu, Yongzhen Peng, Shuying Wang, Jinlong Zuo, Yayi Wang, Jianhua Guo, Development and experimental evaluation of a steady-state model for the step-feed biological nitrogen removal process, Chin. J. Chem. Eng. (2) (2007).

[6] Guibing Zhu, Yongzhen Peng, Baikun Li, Jianhua Guo, Qing Yang, Shuying Wang, A critical review of biological nitrogen removal from wastewater, Rev. Environ. Contam. Toxicol. (2007) 192. 
[7] G.B. Zhu, Y.Z. Peng, Theoretical evaluation on nitrogen removal of stepfeed anoxic/oxic activated sludge process, J. Harbin Inst. Technol. 13 (3) (2006) 99-102.

[8] G. Crawford, S. Black, D. Stafford, The step biological nutrient removal process at Lethbridge-over one full year of operation, in: Proceedings of 73rd Annual Conference and Exposition, Anaheim, California, USA, 2000.

[9] J. Fillos, K. Ramalingam, A. Caltiol, Full-scale evaluation of step-feed BNR process at a New York City water pollution control plant, in: Proceedings of 75th Annual Technical Exhibition and Conference, McCormick Place, Chicago, Illinois, USA, 2002.

[10] F. Shigeo, Theoretical analysis on nitrogen removal of the step-feed anoxic-oxic activated sludge process and its application for the optimal operation, Wat. Sci. Technol. 34 (1/2) (1996) 459-466.

[11] L. Larrea, A. Larrea, E. Ayesa, J.C. Rodrigo, M.D. Lopez-Carrasco, J.A. Cortacans, Development and verification of design and operation criteria for the step feed process with nitrogen removal, Wat. Sci. Technol. 43 (1) (2001) 261-268

[12] E. Gorgun, E. Artan, D. Orhon, S. Sozen, Evaluation of nitrogen removal by step feeding in large treatment plants, Wat. Sci. Technol. 34 (1/2) (1996) 253-260.

[13] Y. Sakai, S. Koike, Development of step feed multi stage denitrificationnitrification process, in: Proceedings of Water Environment Federation 71st Annual Conference and Exposition, Orlando, FL, USA, 1998.

[14] G.B. Zhu, Y.Z. Peng, S.Y. Wu, S.Y. Wang, Influence of C/N ratio on the biological nitrogen removal in step-feed process, China Environ. Sci. 25 (6) (2005) 641-645 (in Chinese).

[15] A. Lesouef, M. Payraudeau, F. Rogalla, B. Kleiber, Optimizing nitrogen removal reactor configurations by on-site calibration of the IWAPRC activated sludge model, Wat. Sci. Technol. 25 (6) (1992) 115-123.

[16] Y. Watanabe, S. Okabe, K. Hirate, S. Masuda, Simultaneous removal of organic materials and nitrogen by microaerobic biofilms, Wat. Sci. Technol. 31 (6) (1995) 195-203.

[17] APHA, Standard Methods for the Examination of Water and Wastewater, 19th ed., American Public Health Association/American Water Works Association/Water Environment Federation, Washington, DC, USA, 1995.

[18] M. Henze, C.P.L. Grady, W. Gujer, G.R. Marais, T. Matsuo, A general model for single sludge wastewater treatment system, Wat. Res. 21 (4) (1987) 545-556.

[19] M. Henze, Capabilities of biological nitrogen removal process from wastewater, Wat. Sci. Technol. 23 (6) (1991) 669-679.

[20] G.A. Ekama, I.P. Srebritz, G.R. Marais, Considerations in the process design of nutrient removal activated sludge processes, Wat. Sci. Technol. 18 (6) (1986) 303-318

[21] B.E. Rittmann, Aerobic biological treatment, Environ. Sci. Technol. 21 (1987) 128-136

[22] M. Strous, J.J. Heijnen, J.G. Kuenen, M.S.M. Jetten, The sequencing batch reactor as a powerful tool for the study of slowly growing ammoniumoxidizing microorganiams, Appl. Environ. Microb. 50 (6) (1998) 589-596.
[23] C.S. Huang, N.E. Hopson, Nitrification rate in biological processes, J. Environ. Eng. 24 (1974) 409-416.

[24] K. Brindle, T. Stephenson, The application of membrane biological reactors for the treatment of wastewater, Biotechnol. Bioeng. 49 (5) (1996) 601610.

[25] K.H. Choo, H.D. Stensel, Sequencing batch membrane reactor treatment: nitrogen removal and membrane fouling evaluation, Wat. Environ. Res. 72 (6) (2000) 1389-1406.

[26] B. Günder, K. Krauth, Replacement of secondary clarification by membrane separation-results with plate and hollow fibre modules, Wat. Sci. Technol. 38 (4/5) (1998) 383-393.

[27] W.J. Davies, M.S. Le, C.R. Heath, Intensified activated sludge process with submerged membrane microfiltration, Wat. Sci. Technol. 38 (4/5) (1998) $421-428$.

[28] K. Hanaki, C. Wantawin, S. Ohgaki, Nitrification at low level of DO with and without organic loading in a suspended growth reactor, Wat. Res. 24 (1990) 297-302.

[29] S. Hisashi, N. Yoshiyuki, O. Hideki, O. Staoshi, Effect of oxygen concentration nitrification and denitrification in single activated sludge flocs, Biotechnol. Bioeng. 83 (2003) 604-607

[30] S. Wyffels, K. Pynaert, P. Boeckx, W. Verstraete, O. Van Cleemput, Identification and quantification of nitrogen removal in a rotating biological contactor by $15 \mathrm{~N}$ tracer techniques, Wat. Res. 37 (2003) 1252 1259

[31] D. Patureau, N. Bernet, R. Moletta, Effect of oxygen on denitrification in continuous chemostat culture with Comamonas sp. strain SGLY2, J. Ind. Microbiol. 16 (1995) 124-128

[32] A. Neef, A. Zaglauer, H. Meier, R. Amann, H. Lemmer, K.H. Schleifer, Population analysis in a denitrification sand filter: conventional and in situ of Paracoccus spp. in methanol-fed biofilms, Appl. Environ. Microbiol. 62 (12) (1996) 4329-4339.

[33] M.S.M. Jetten, M. Schmid, I. Schmidt, M. Wubben, U. van Dongen, W Abma, et al., Improved nitrogen removal by application of new nitrogen cycle bacteria, Rev. Environ. Sci. Biotechnol. 1 (2002) 51-63.

[34] L.A. Robertson, E.W.J. Niel, R.A.M. Torremans, J.G. Kuenen, Simultaneous nitrification and denitrification in aerobic chemostat cultures of Thiosphaera pantotropha, Appl. Environ. Microbiol. 54 (11) (1988) 2812-2818.

[35] I. Schmidt, O. Sliekers, M. Schmid, E. Bock, Fuerst John, J.G. Kuenen S.M. Jetten Mike, M. Strous, New concepts of microbial treatment processes for the nitrogen removal in wastewater, FEMS Microbiol. Rev. 27 (2003) 481-492.

[36] Guibing Zhu, Yongzhen Peng, Shuyun Wu, Shuying Wang, Simultaneous nitrification and denitrification in step-feed biological nitrogen removal process, J. Environ. Sci., Accepted 2006

[37] B.R. Zhang, Floc size distribution and bacterial activities in membrane separation activated sludge process for small-scale wastewater treatment/reclaimation, Wat. Sci. Technol. 35 (6) (1997) 37-44. 